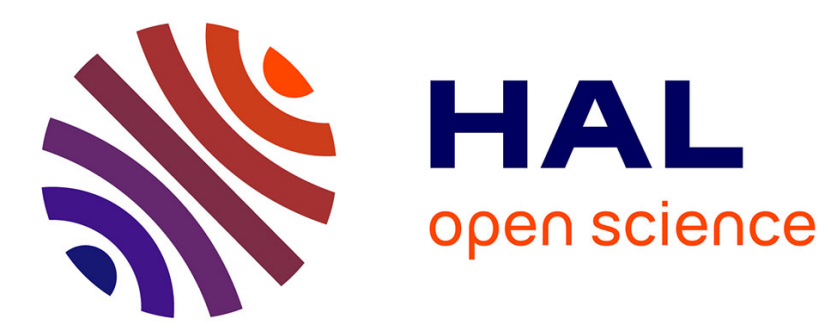

\title{
Effects of thermal damage on physical properties and cracking behavior of ultrahigh-performance fiber-reinforced concrete
}

Hui Bian, Kinda Hannawi, Mokhfi Takarli, Laurent Molez, William Prince

\section{- To cite this version:}

Hui Bian, Kinda Hannawi, Mokhfi Takarli, Laurent Molez, William Prince. Effects of thermal damage on physical properties and cracking behavior of ultrahigh-performance fiber-reinforced concrete. Journal of Materials Science, 2016, 51 (22), pp.10066-10076. 10.1007/s10853-016-0233-9 . hal-01365982

\author{
HAL Id: hal-01365982 \\ https://hal.science/hal-01365982
}

Submitted on 13 Sep 2016

HAL is a multi-disciplinary open access archive for the deposit and dissemination of scientific research documents, whether they are published or not. The documents may come from teaching and research institutions in France or abroad, or from public or private research centers.
L'archive ouverte pluridisciplinaire $\mathbf{H A L}$, est destinée au dépôt et à la diffusion de documents scientifiques de niveau recherche, publiés ou non, émanant des établissements d'enseignement et de recherche français ou étrangers, des laboratoires publics ou privés. 


\title{
Effects of thermal damage on physical properties and cracking behavior of ultrahigh- performance fiber-reinforced concrete
}

\author{
Hui Bian${ }^{1}$, Kinda Hannawi ${ }^{1, *}$, Mokhfi Takarli², Laurent Molez ${ }^{1}$, and William Prince ${ }^{1}$ \\ ${ }^{1}$ Laboratoire de Génie Civil et Génie Mécanique (LGCGM), INSA-Rennes, 20 Avenue des Buttes de Coësmes, \\ CS 70839, 35708 Rennes Cedex 7, France \\ 2 Groupe d'Etude des Matériaux Hétérogènes (GEMH), Equipe Génie Civil et Durabilité, Université de Limoges, \\ 19300 Egletons, France
}

Address correspondence to E-mail: Kinda.hannawi@insa-rennes.fr

\begin{abstract}
In this work, we study the impact of thermal damage on the physical and mechanical properties of ultrahigh-performance fiber-reinforced concrete (UHPFRC), especially on their cracking process under compressive loading. Four mixtures of UHPFRC were prepared using identical composition but reinforced with different types of fibers: mineral fibers (Steel or Wollastonite) or organic fibers (PP or PVA) and compared with that without fibers (UHPC). To induce a thermal damage on UHPFRC, the samples were subjected to temperatures ranging from 150 to $400{ }^{\circ} \mathrm{C}$. After each degradation stage, the gas permeability and the P-wave velocity were measured. The mechanical behavior under loading has been studied using a uniaxial compression test which combines the gas permeability and the acoustic emission measurement. The results show that the melting of organic fibers at approximately $180{ }^{\circ} \mathrm{C}$ builds a tunnel across the cement paste and increases brutally the gas permeability. At $400{ }^{\circ} \mathrm{C}$ treatment, a decrease of compression strength by $30 \%$ and of Young modulus by approximately $60 \%$ was observed. However, we can see that the thermal damage results a decrease in the threshold of initial cracking $\left(r_{k-}\right.$ ci) and that of unstable cracking $\left(\mathrm{r}_{\mathrm{k}-\mathrm{p}}\right)$, and this can be explained by the initiation of new cracks and their coalescence.
\end{abstract}




\section{Introduction}

In the past years, ultrahigh-performance fiber-reinforced concretes (UHPFRC) have become a subject of interest for engineers. This interest is due to the fact that the fibers can improve various characteristics of normal ultrahigh-performance concretes (UHPC) [1]. The UHPC is made of a very dense cementitious matrix that makes it more resistant and more durable than normal concrete but this results in a brittle behavior [2]. The incorporation of fibers reduces shrinkage and cracking and provides ductility both under tension as well as compression load [3-7].

It should be noted that fiber-cement paste interface and aggregate-cement paste interface have a key role in the mechanical performances of concretes, especially in their cracking under external solicitations. Indeed, concrete microcracking generally occurs firstly in those interfaces or in the cement paste around them, due to their weakness and to stress concentration $[8,9]$.

A lot of published data indicate that the fiber's impact on concrete is modified by elevated temperature. For example, if organic fiber (polypropylene fiber "PP") is used to reinforce concrete, the melting of the fiber at $170{ }^{\circ} \mathrm{C}$ builds tunnels that can reduce significantly the internal gas pressure in concrete and then decrease the thermal cracking of concrete [10-12]. Even if fibers resist high temperatures (for example steel fibers or mineral fibers), the fiber-cement paste interface (interfacial transition zone) degrades rapidly when concrete is exposed to high temperatures. This is due to the fact that the CSH crystals that mainly constitute this interface decompose around $180{ }^{\circ} \mathrm{C}$ and accelerate the concrete thermal degradation [13-15]. In addition, the thermal expansion difference between the fibers and the cement paste may cause important thermal stresses and lead to thermal cracking at high temperature [16]. For example, the coefficient of thermal expansion at $20{ }^{\circ} \mathrm{C}$ is about $3910^{-6} \mathrm{~K}^{-1}$ for limestone aggregate, $13910^{-6} \mathrm{~K}^{-1}$ for steel fiber, $6.5910^{-6} \mathrm{~K}^{-1}$ for Wollastonite fiber, and $15.5910^{-6} \mathrm{~K}^{-1}$ for cement paste [17].

The main objective of this study is to evaluate the impact of elevated temperatures on the physical characteristics and the mechanical behavior of four UHPFRC. The thermal damage is induced by heating the concrete samples up to temperatures ranging from 150 to $400{ }^{\circ} \mathrm{C}$. The physical properties of the specimens were examined by measuring the apparent permeability and the P-wave velocity. The mechanical behavior under loading has been studied using a uniaxial compression test which combines the gas permeability and the acoustic emission (AE) measurement. The P-wave velocity test provides an accurate estimation of the total damage on the material, while the permeability measurement gives indications on the connections of the porous network. This network constitutes a possible pathway for aggressive solutions penetration. The mechanical test accompanied with the gas permeability and the $\mathrm{AE}$ measurement allows us to follow the cracking process under mechanical loading.

\section{Material and experimental procedure}

\section{Material and mixtures}

The reference specimens in this work were UHPC. The first type of UHPFRC specimens was reinforced with $1 \%$ volume of mineral fibers (steel or wollastonite). The second type of UHPFRC was reinforced with $1 \%$ volume of organic fibers (Polypropylene "PP" or Polyvinyl alcohol "PVA"). The concrete was prepared using European cement (CEM I 52.5N) containing $1.2 \%$ mass of limestone filler and $4.9 \%$ mass of siliceous filler. The aggregate used is normalized silica sand having $1,730 \mathrm{~kg} \mathrm{~m}^{-3}$ bulk density and 2.65 specific gravity. The water/cement ratio was 0.27 . The fibers characteristics are reported in Table 1. The experimental investigations were performed on cylindrical specimens $(40 \times 60) \mathrm{mm}$. The top and lower surfaces of the specimens were properly polished before the test to ensure two sufficiently smooth and parallel surfaces. Three specimens were prepared for each composite and each test in order to calculate their average. 
Table 1 Fibers properties

\begin{tabular}{lcclllll}
\hline Fibers & $\mathrm{L}(\mathrm{mm})$ & $\phi(\mu \mathrm{m})$ & Melting pt. $\left({ }^{\circ} \mathrm{C}\right)$ & $\rho\left(\mathrm{kg} / \mathrm{m}^{3}\right)$ & $\alpha(10-6 \mathrm{~K}-1)$ & $\sigma_{\tau}(\mathrm{GPa})$ & $\mathrm{E}(\mathrm{GPa})$ \\
\hline Steel & 50 & 600 & 1370 & 7800 & 13 & $1-3$ & 200 \\
Wollastonite & 3 & 100 & 1540 & 3000 & 6.5 & $2.7-4.1$ & $303-$ \\
PP & 6 & 28 & $130-171$ & 915 & 100 & $0.03-0.04$ & $0.9-1.5$ \\
PVA & 12 & 100 & $150-190$ & 1300 & 75 & 1.23 & 29.5 \\
\hline
\end{tabular}

$\alpha$ is the Thermal expansion coefficient

\section{Heat treatment}

The concrete specimens were heated in a furnace at a rate of $1{ }^{\circ} \mathrm{C} \min ^{-1}$ until the maximum temperature is reached (Fig. 1). This low rate of heating ensured that cracking would result only from the temperature increase and not due to thermal gradients within the sample.

The specimens were heated up to $150,200,300$, or $400{ }^{\circ} \mathrm{C}$, and held at these temperatures for $4 \mathrm{~h}$. They were then cooled down to room temperature at a rate of $-0.3{ }^{\circ} \mathrm{C} \mathrm{min}{ }^{-1}$. All the treated specimens were kept in a desiccator during the period preceding the test.

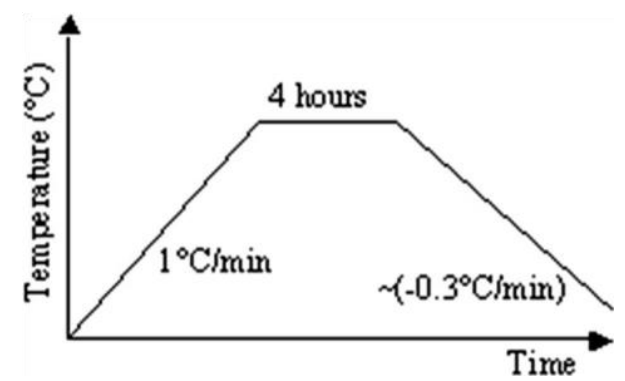

Figure 1 Thermal degradation of concrete samples (heating process).

\section{Gas permeability test}

In this study, an inert gas (helium) was used for the permeability measurement. The pore water was removed from the specimen by drying them at $105{ }^{\circ} \mathrm{C}$ to obtain a constant mass then keeping them in a desiccator for $24 \mathrm{~h}$ prior to the measurement $[18,19]$. The test was performed using a gas-flow method keeping a constant percolating gas pressure at the bottom of the samples. The steady-state gas flow was considered established when the variation of outflow gas flux measured was less than $2 \%$ during a period of $10 \mathrm{~min}$.

The apparent permeability coefficient $\mathrm{K}_{\mathrm{a}}\left(\mathrm{m}^{2}\right)$ was then calculated by the Darcy relationship [20] for the laminar flow of a compressible fluid through a porous body under steady-state conditions using Eq. 1:

$$
K_{\mathrm{a}}=\frac{2 \mu Q L P_{2}}{S\left(P_{1}^{2}-P_{2}^{2}\right)},
$$

where $K_{a}\left(\mathrm{~m}^{2}\right)$ is the apparent gas permeability of the specimen; $\mathrm{Q}\left(\mathrm{ml} \mathrm{min}{ }^{-1}\right)$ is the outflow gas flux measured; $\mathrm{P}_{1}$ is the constant percolate gas pressure (we have chosen $0.6 \mathrm{MPa}$ ); $\mathrm{P}_{2}$ is the atmospheric pressure $\left(\mathrm{P}_{2}=0.1 \mathrm{MPa}\right) ; \mu$ is the dynamic 
viscosity of helium gas $=2 \times 10^{-5}(\mathrm{Pas})$ at $20^{\circ} \mathrm{C} ; \mathrm{S}$ is the crosssectional area of the specimen; and $\mathrm{L}$ is the length of the specimen.

\section{P-wave velocity test}

P-wave velocity measurement is a very convenient method for the nondestructive testing of a given material [21-23]. Pwave velocity $\mathrm{V}_{\mathrm{P}}$ is calculated using the transmission travel time of an acoustic pulse along the axial direction of the samples. The experimental setup includes a waveform generator, two piezoelectric transducers (with a resonant frequency of 500 $\mathrm{kHz}$ ) mounted on the sample holder, and a numerical oscilloscope board connected to a computer. A constant pressure is systematically applied using a constant mass to ensure a tight contact between the concrete specimen and the transducers. We have chosen water as the coupling agent between the sample and the transducers in order to transmit the ultrasonic energy to the sample and also not to affect the gas permeability measurement with the use of other more viscous coupling agents. The travel time was measured using a program developed under the LABVIEW system with a resolution of $501 \mathrm{s.}$

\section{Tests under mechanical loading}

\section{Deformation measurement}

The cylindrical concrete specimens with the dimensions of $40 \mathrm{~mm}$ diameter and $60 \mathrm{~mm}$ length were loaded with a uniaxially applied stress in the direction of the longer axis of the specimens, at a loading rate of $150 \mathrm{~N} \mathrm{~s}^{-1}$. The axial and circumferential strains in the sample were measured using two strain gauges directly bonded to the specimen: the first one parallel to the specimen longitudinal axis and the second one along the circumference. In order to calculate the volumetric strain $\left(\mathrm{e}_{\mathrm{v}}\right)$, the following equation has been used (2):

$$
\varepsilon_{\mathrm{v}}=\varepsilon_{\mathrm{a}}+2 \varepsilon_{\mathrm{t}},
$$

where $\varepsilon_{\mathrm{a}}$ and $\varepsilon_{\mathrm{t}}$ are the axial and the transverse (lateral) strains, respectively.

\section{Permeability changes and AE measurement}

In this study, strains, changes in permeability, and acoustic emission (AE) were simultaneously measured during the uniaxial compressive test. To perform these measurements we have used a specific cell, a stress-flow-AE cell, that is based on a modified triaxial cell design (Fig. 2) with a special loading piston to enable the flowing of gas along the core axis during tests [22]. The percolated gas is uniformly distributed over the full face of the sample. The experiment began when all the cracks were filled with the gas and the steady-state flow was reached, which typically required between 15 min to an hour depending on the performance of the concrete specimen. During the experiment, once all the cracks were filled, a slight stress was found to cause an instantaneous and stable flow-rate change particularly at high gas pressure. Preliminary tests were performed to determine a proper loading rate. Since the flow rate is proportional to the apparent permeability, we have used this parameter to represent the data obtained.

The AE transducer [24] was positioned on the top plate of the cell. The transducer position is not very important in our investigation. Butt [25] showed that positioning the transducer in line with the axes of the loading piston and the core sample enables the recording of the direct $\mathrm{AE}$ waves generated in the sample, as opposed to the fully or partially reflected waves where the transducer positioned on the side of the loading piston or on the bottom plate of the cell. The recording of direct $\mathrm{AE}$ waves is important for the full-waveform analysis and, in conjunction with a source transducer, for velocity and attenuation measurements. The AE signals were first amplified and then sampled at $20 \mathrm{MHz}$. In this study, analysis of the AE signals was performed using a simple approach based on estimation of cumulative events energy (event rate during a period of $100 \mathrm{~ms}$ ). 


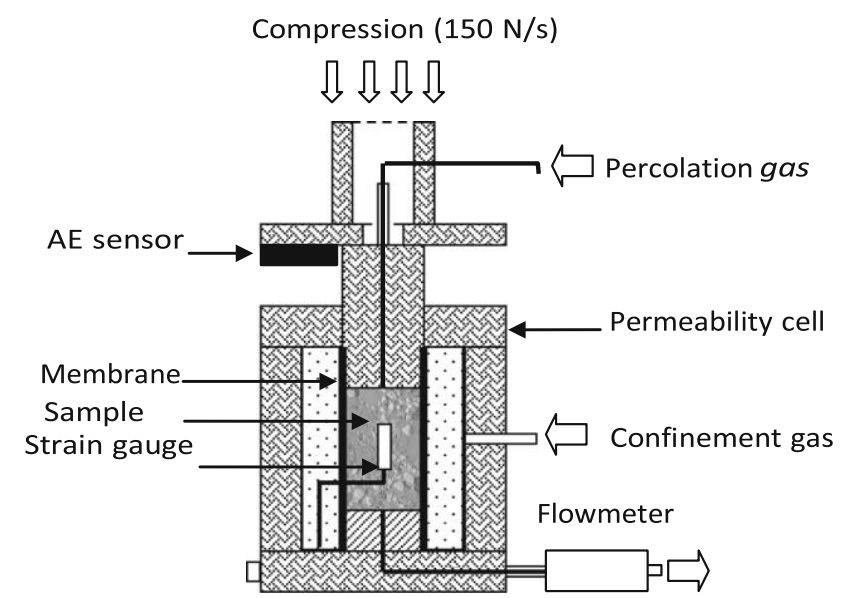

Figure 2 Tests under mechanical loading.

\section{Mechanical and cracking behavior under compressive stress}

Permeability measurement is highly sensitive to crack development in materials because it is directly dependent on the geometry of the porous network and its interconnectivity. For this reason, it is interesting to use it to characterize the failure process in materials under mechanical test. Therefore, in this study, we have chosen to measure the deformations, the permeability changes, and the acoustic emission (AE) simultaneously during the uniaxial compressive test. To explain the different phases under the compressive stress, we have presented in Fig. 3a and b, the curves of stress-strain and the curves stress-gas flow of a reference specimen. We can reveal four phases during the specimen loading [26-28]; they provide the comparison keys between the different concretes studied.

Phase 1: $\left(\sigma<\sigma_{\mathrm{k}-\mathrm{s}}\right)$ : phase of the closing of pre-existing cracks

Crack closure occurs at the initial stage of loading. During this stage, the permeability decreases by a value of $\Delta \mathrm{K}$ (from $\mathrm{K}_{0}$ to $\mathrm{K}_{\mathrm{s}}$ ), and this is mainly due to the decrease in the volume accessible to the fluid of percolation. Indeed, the loading causes a reduction of the micropores size as well as changes in the geometry and the connectivity of cracks and their closure.

Phase 2: $\left(\sigma_{\mathrm{k}-\mathrm{s}}<\sigma<\sigma_{\mathrm{k}-\mathrm{ci}}\right)$ : phase of permeability stabilization

During this stage, the volumetric gas flow rate remains constant during mechanical loading. We consider that there is a combination of crack initiation, crack growth, and crack closure. The recorded AE, in this phase, reveals quasicontinuous bursts of microbruits of low intensity reflecting the frictions between the grains of the material and the lips of closed cracks. During this phase, the longitudinal strain is linear; transverse deformation ceases to be linear and tends to increase. 
(a)

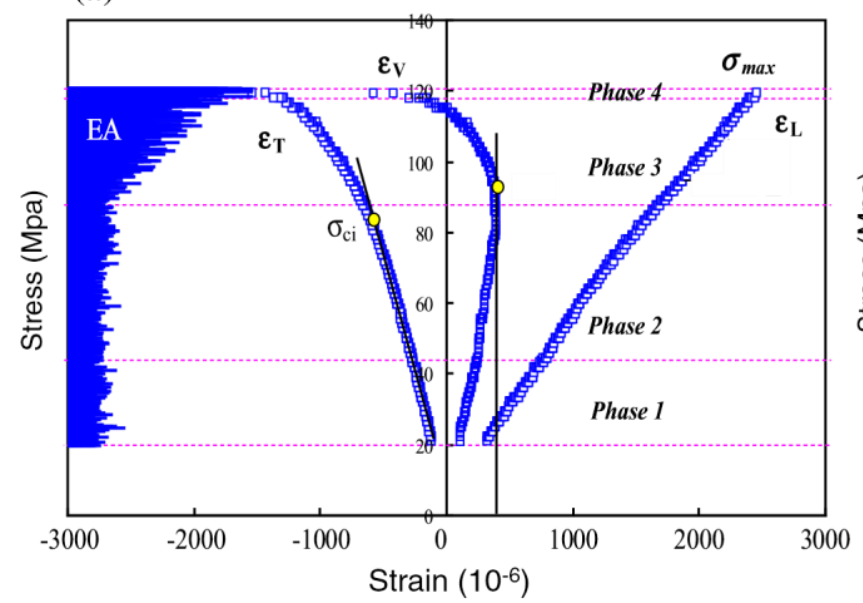

(b)

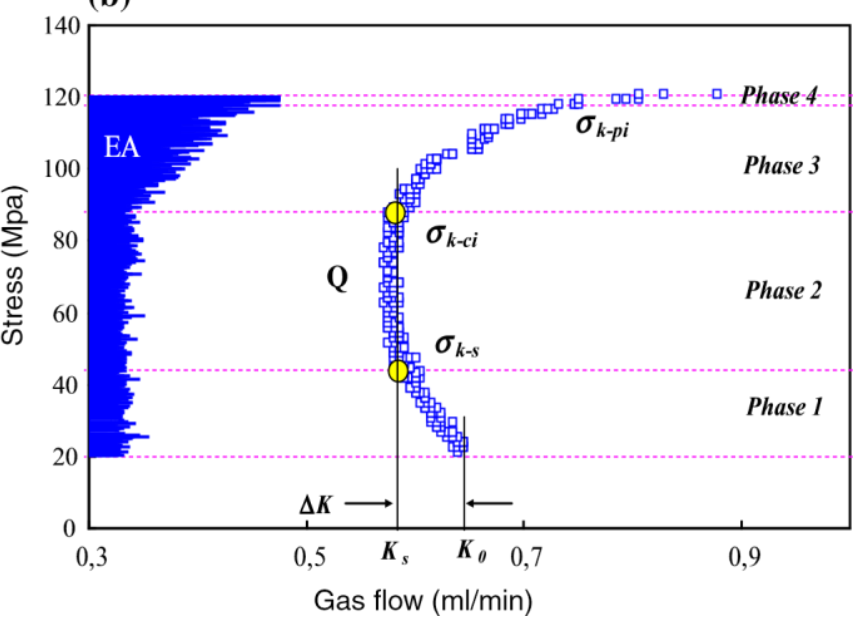

Figure 3 Curves of stress-strain (a) and stress-gas flow (b) of a reference specimen under the compressive stress.

Phase 3: $\left(\sigma_{\mathrm{k}-\mathrm{c}}<\sigma<\sigma_{\mathrm{k}-\mathrm{p}}\right)$ : phase of stable microcracking

The third phase indicates an increase of permeability $(\mathrm{K})$; it corresponds to the extension of existing cracks and the creation of new microcracks; it is caused by the increase and concentration of stress. The microcracking produced during this phase generates short and isolated microbruits that become progressively more frequent as loading increases. During this phase, the longitudinal deformation remains quasilinear and does not reflect in any way the irreversible transformation demonstrated by permeability change and acoustic signal. The transversal deformation shows a sharp increase of Poisson's ratio and the volumetric behavior becomes dilatant.

Phase 4: $\left(\sigma>\sigma_{\mathrm{k}-\mathrm{p} i}\right)$ : phase of unstable crack propagation

During the last phase permeability increases rapidly. This increase corresponds to the development and the multiplication of cracks. The cracks propagate in an unstable manner under the effect of stress concentrations or due to the coalescence of the neighboring cracks. During this phase, the intensity of the isolated noises increases along with their frequency of occurrence. The transversal strain grows simultaneously with the volume expansion of the specimen.

\section{Results and discussion}

\section{Effects of thermal damage on gas permeability}

The apparent gas permeability values of UHPC and UHPFRC specimens are given in Table 2. The experimental results reveal that at $105^{\circ} \mathrm{C}$ the specimens reinforced with fiber UHPFRC have a higher gas permeability (about $10^{-17}$ ) compared to the UHPC specimens (about $10^{-18}$ ). These results may be attributed to the quality of interface fibers/cement paste.

In order to compare the different mixtures at different temperatures and illustrate the relevant changes, the gas permeability values after the heat treatment have been normalized with respect to the initial value measured at $105^{\circ} \mathrm{C}$ as shown in Fig. 4 .

The permeability curves show two kinds of distinct behavior according to whether the incorporated fibers are mineral or organic: 
- For mineral fiber specimens, firstly, permeability decreases slightly when temperature is increased from 105 to $150{ }^{\circ} \mathrm{C}$. This could be due to the closure of certain cracks, or the carbonation of some portlandite or to some complementary hydration of the cement grain in contact with the evaporating water. Other authors [29] have reported similar observations.

Secondly, permeability slightly increases when temperature is increased from 150 to $300{ }^{\circ} \mathrm{C}$ and even more significantly between 300 and $400{ }^{\circ} \mathrm{C}$. These evolutions can be explained by the modification of the hydrated phases of the cement paste as concrete temperature increases [30]. In fact, above $170{ }^{\circ} \mathrm{C}$ the dehydration of calcium silicate hydrate (CSH) begins, and continues its progressive decomposition particularly when temperature exceeds $300{ }^{\circ} \mathrm{C}$. The decomposition of the portlandite and limestone crystals occurs later at 460 and $800{ }^{\circ} \mathrm{C}$, respectively. Consequently, in the case of this study, since the temperature did not exceed $400{ }^{\circ} \mathrm{C}$, we can state that the main degradation mechanisms in the concrete are due to the dehydration of $\mathrm{CSH}$, and this can produce a discontinuity and a cracking in the cement paste and therefore increase permeability.

- For organic fiber specimens: permeability increases significantly when temperature exceeds $150{ }^{\circ} \mathrm{C}$. This is due to the melting of the organic fibers that left tunnels for the gas flow as shown in Fig. 5.

Table 2 Apparent permeability $\left(\mathrm{m}^{2}\right)$ of intact and heated concrete samples

\begin{tabular}{llllll}
\hline Concretes & $105{ }^{\circ} \mathrm{C}$ & $150{ }^{\circ} \mathrm{C}$ & $200{ }^{\circ} \mathrm{C}$ & $300{ }^{\circ} \mathrm{C}$ & $400{ }^{\circ} \mathrm{C}$ \\
\hline UHPC & $9.89 \mathrm{E}-18 \pm 11.26 \%$ & $7.97 \mathrm{E}-18 \pm 7.23 \%$ & $1.52 \mathrm{E}-17 \pm 0.82 \%$ & $5.20 \mathrm{E}-17 \pm 2.71 \%$ & $2.10 \mathrm{E}-16 \pm 1.82 \%$ \\
UHPFRC & & & & & \\
$\quad$ Steel & $1.19 \mathrm{E}-17 \pm 0.92 \%$ & $8.65 \mathrm{E}-18 \pm 2.71 \%$ & $1.97 \mathrm{E}-17 \pm 3.59 \%$ & $8.86 \mathrm{E}-17 \pm 4.88 \%$ & $2.76 \mathrm{E}-16 \pm 2.73 \%$ \\
Wollastonite & $1.08 \mathrm{E}-17 \pm 7.35 \%$ & $7.09 \mathrm{E}-18 \pm 11.69 \%$ & $1.47 \mathrm{E}-17 \pm 10.88 \%$ & $6.62 \mathrm{E}-17 \pm 5.49 \%$ & $2.15 \mathrm{E}-16 \pm 8.46 \%$ \\
PP & $1.51 \mathrm{E}-17 \pm 10.49 \%$ & $3.14 \mathrm{E}-17 \pm 13 \%$ & $4.54 \mathrm{E}-15 \pm 9.71 \%$ & $1.76 \mathrm{E}-14 \pm 2.4 \%$ & $3.56 \mathrm{E}-14 \pm 8.04 \%$ \\
PVA & $4.35 \mathrm{E}-17 \pm 2.01 \%$ & $7.43 \mathrm{E}-17 \pm 12.92 \%$ & $4.02 \mathrm{E}-16 \pm 11.94 \%$ & $4.40 \mathrm{E}-15 \pm 4.8 \%$ & $1.51 \mathrm{E}-14 \pm 4.88 \%$ \\
\hline
\end{tabular}

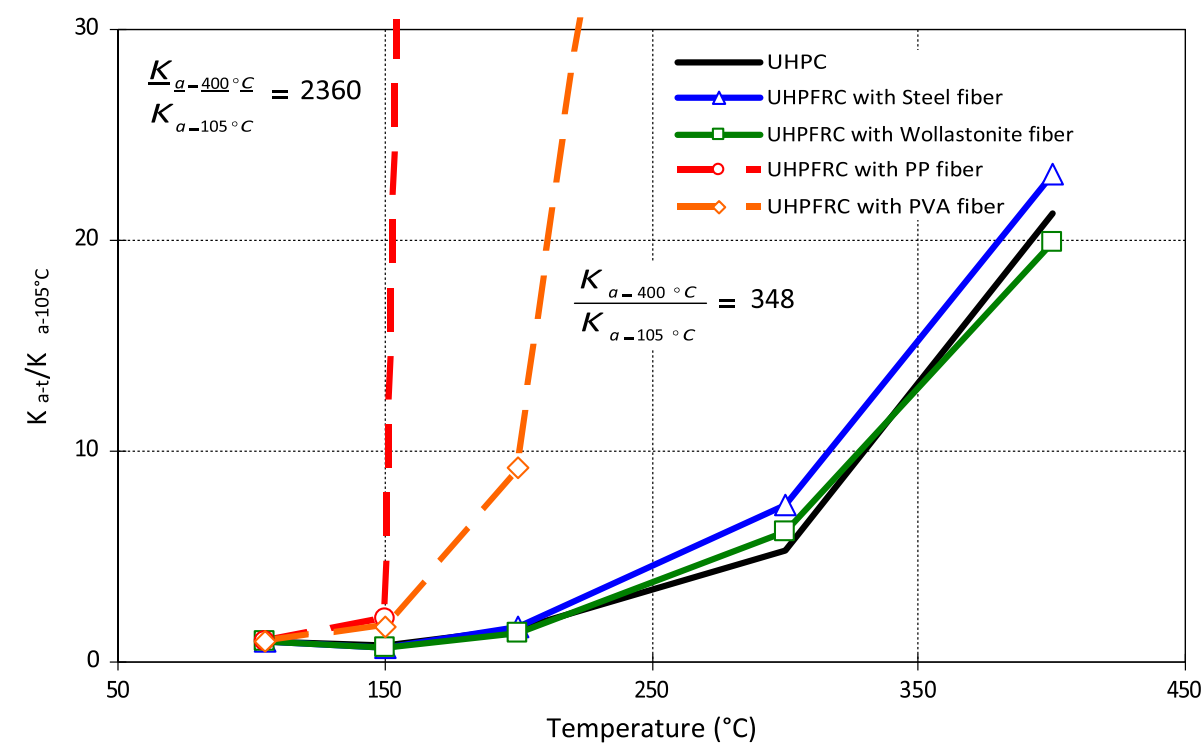

Figure 4 Gas permeability of the specimens after the heat treatment. 


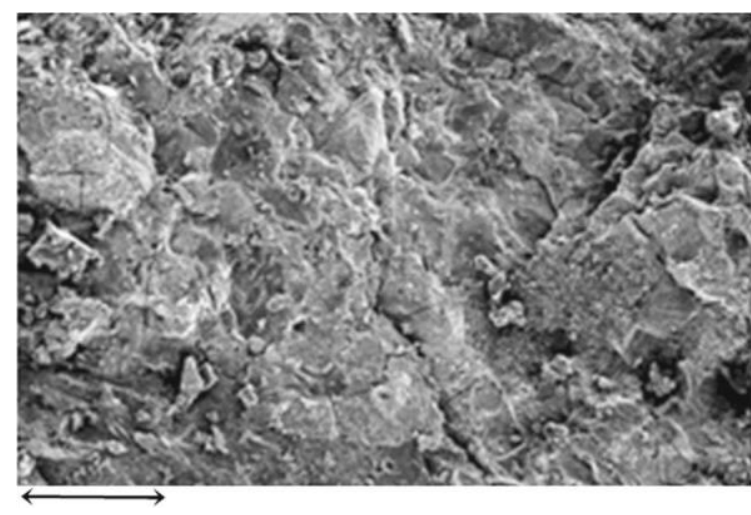

$100 \mu \mathrm{m}$

UHPC specimen after heating at $300^{\circ} \mathrm{C}$

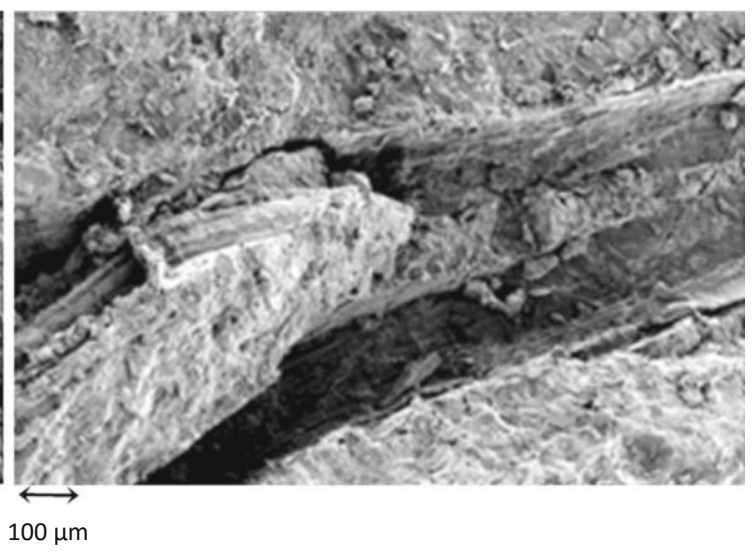

UHPC specimen reinforced with PP fibers after heating at $300^{\circ} \mathrm{C}$

Figure 5 Melting of PP fiber at $300{ }^{\circ} \mathrm{C}$.

\section{Effects of thermal damage on P-wave velocity}

The P-waves velocity in UHPC and UHPFRC specimens are summarized in Table 3. The values after the heat treatment have been normalized with respect to the initial value measured at $105^{\circ} \mathrm{C}$ and presented in Fig. 6 .

The results show that the P-wave velocity of all mixtures at $105^{\circ} \mathrm{C}$ is around the same order of magnitude (around $5000 \mathrm{~m}$ $\mathrm{s}^{-1}$ ). As expected, there is a negative correlation between $\mathrm{P}$-wave velocity curves and the damage induced by the heat treatment. All the samples tested show that $\mathrm{P}$-wave velocity is less affected by temperature elevation from 105 to $150{ }^{\circ} \mathrm{C}$. Above $150{ }^{\circ} \mathrm{C}$, samples showed a decrease in velocity (about $6 \%$ at $200{ }^{\circ} \mathrm{C}$ ). Velocity decrease becomes even more important between 200 and $400{ }^{\circ} \mathrm{C}$ (more than $28 \%$ at $400{ }^{\circ} \mathrm{C}$ ). These results are in agreement with the permeability measurements presented in the previous section since an elevated temperature induces an increase in global porosity. However, only a minor difference exists between mineral and organic fibers. This can be explained as P-wave velocity is directly impacted by the overall damage and the global porosity increase. But it does not give indications on the interconnection of this porosity, and it does not take into account the creation of bridges caused by the organic fibers melting as the case of the permeability. Therefore, we can not show a significant difference between organic and mineral fiber.

Table 3 P-wavevelocity $(\mathrm{m} / \mathrm{s})$ of intact and heated concrete samples

\begin{tabular}{llllll}
\hline Concretes & $105{ }^{\circ} \mathrm{C}$ & $150{ }^{\circ} \mathrm{C}$ & $200{ }^{\circ} \mathrm{C}$ & $300{ }^{\circ} \mathrm{C}$ & $400{ }^{\circ} \mathrm{C}$ \\
\hline UHPC & $5058 \pm 0.83 \%$ & $5005 \pm 0.35 \%$ & $4792 \pm 0.20 \%$ & $4336 \pm 0.19 \%$ & $3675 \pm 1.67 \%$ \\
UHPFRC & & & & & \\
Steel & $5198 \pm 0.70 \%$ & $5121 \pm 0.2 \%$ & $4857 \pm 0.05 \%$ & $4376 \pm 0.18 \%$ & $3771 \pm 0.85 \%$ \\
Wollastonite & $5042 \pm 0.98 \%$ & $5085 \pm 0.37 \%$ & $4850 \pm 0.19 \%$ & $4418 \pm 0.72 \%$ & $3799 \pm 1.08 \%$ \\
PP & $4881 \pm 0.06 \%$ & $4838 \pm 0.06 \%$ & $4614 \pm 0.74 \%$ & $3998 \pm 0.29 \%$ & $3359 \pm 0.80 \%$ \\
PVA & $5001 \pm 0.22 \%$ & $4939 \pm 0.36 \%$ & $4676 \pm 0.21 \%$ & $4192 \pm 0.40 \%$ & $3598 \pm 1.50 \%$ \\
\hline
\end{tabular}




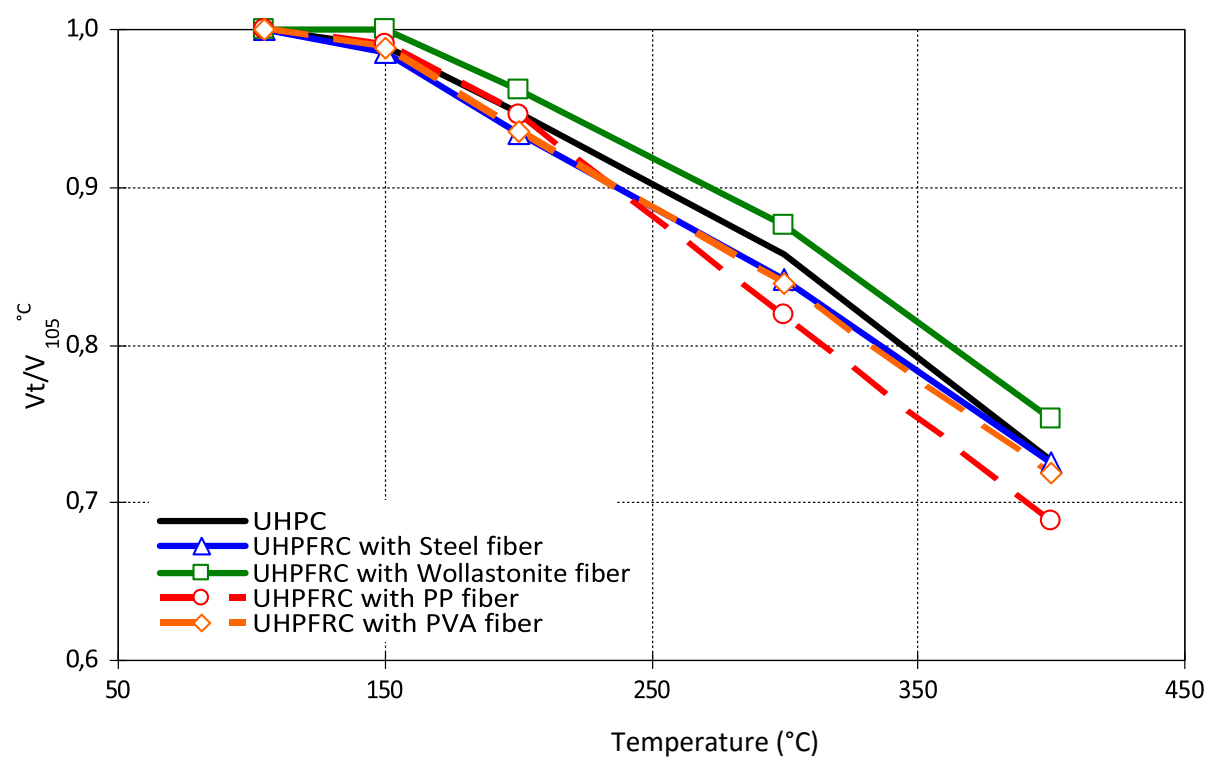

Figure 6 P-wave velocity in the concrete specimens after heat treatment.

\section{Effects of thermal damage on mechanical behavior}

\section{General behavior under compressive load}

Figure 7a represents the stress-strain curves of intact and thermally damaged PP-concretes at $400{ }^{\circ} \mathrm{C}$. The evolutions are practically the same for all other concretes.

The following observations can be removed on the stress-strain curves:

- The stress-longitudinal strain curve $\left(\sigma-\varepsilon_{\mathrm{L}}\right)$ shows that heat treatment induces a sharp decrease of Young's modulus and a much greater strain at failure (comparison $\varepsilon_{\mathrm{L}}$ and $\varepsilon_{\mathrm{L}-400}{ }^{\circ} \mathrm{C}$ ).

- On the stress-transversal strain curve $\left(\sigma-\varepsilon_{\mathrm{T}}\right)$, we can see that the heat treatment of sample induces a greater deformability and a significant and early increase in Poisson's ratio (comparison $\varepsilon_{\mathrm{T}}$ and $\varepsilon \mathrm{T}-400^{\circ} \mathrm{C}$ ).

- The stress-volumetric strain curve $(\sigma-\varepsilon \mathrm{V})$ is even more telling. It particularly reveals a contracting phase more pronounced on the sample heated to $400{ }^{\circ} \mathrm{C}$. The beginning of mechanical loading serves mainly to close the cracks created during heating (comparison $\varepsilon_{\mathrm{V}}$ and $\varepsilon_{\mathrm{V}-400}{ }^{\circ} \mathrm{C}$ ).

Figure $7 \mathrm{~b}$ reproduces the evolution of the gas flow rate recorded simultaneously with the stress-strain curves.

The main observations are as follows:

- After heating to $400{ }^{\circ} \mathrm{C}$, the initial flow before loading is clearly higher than that of intact concrete: $\mathrm{Q} 400{ }^{\circ} \mathrm{C}$ of 23.15 $\mathrm{ml} \mathrm{min}{ }^{-1}$ versus $\mathrm{Q}$ intact of $3.28 \mathrm{ml} \mathrm{min}^{-1}$.

- On the curve of concrete heated to $400{ }^{\circ} \mathrm{C}$, the tightening phase (up to $\sigma_{\mathrm{k}-\mathrm{s}}$ ) is characterized by a greater decrease of the gas flow, corresponding to the closing of the cracks created during heating (more convex curve, $\Delta \mathrm{Q}$ greater).

- The constraints at the microcracking threshold $\sigma_{\mathrm{k}-\mathrm{ci}}$ and at the propagation threshold $\sigma_{\mathrm{k}-\mathrm{pi}}$ are significantly lower than the unheated concrete: 41.7 versus $83.2 \mathrm{MPa}$ for $\mathrm{r}_{\mathrm{k}-\mathrm{c} i}$ and 58.3 versus $106 \mathrm{MPa}$ for $\mathrm{r}_{\mathrm{k} \text {-pi }}$.

- During the phase of unstable crack propagation $\left(\sigma>\sigma_{\mathrm{k}-\mathrm{p} i}\right.$ ), we can observe that the intensity of the bruits and their occurrence frequency increases significantly in the specimen heated to $400{ }^{\circ} \mathrm{C}$. 

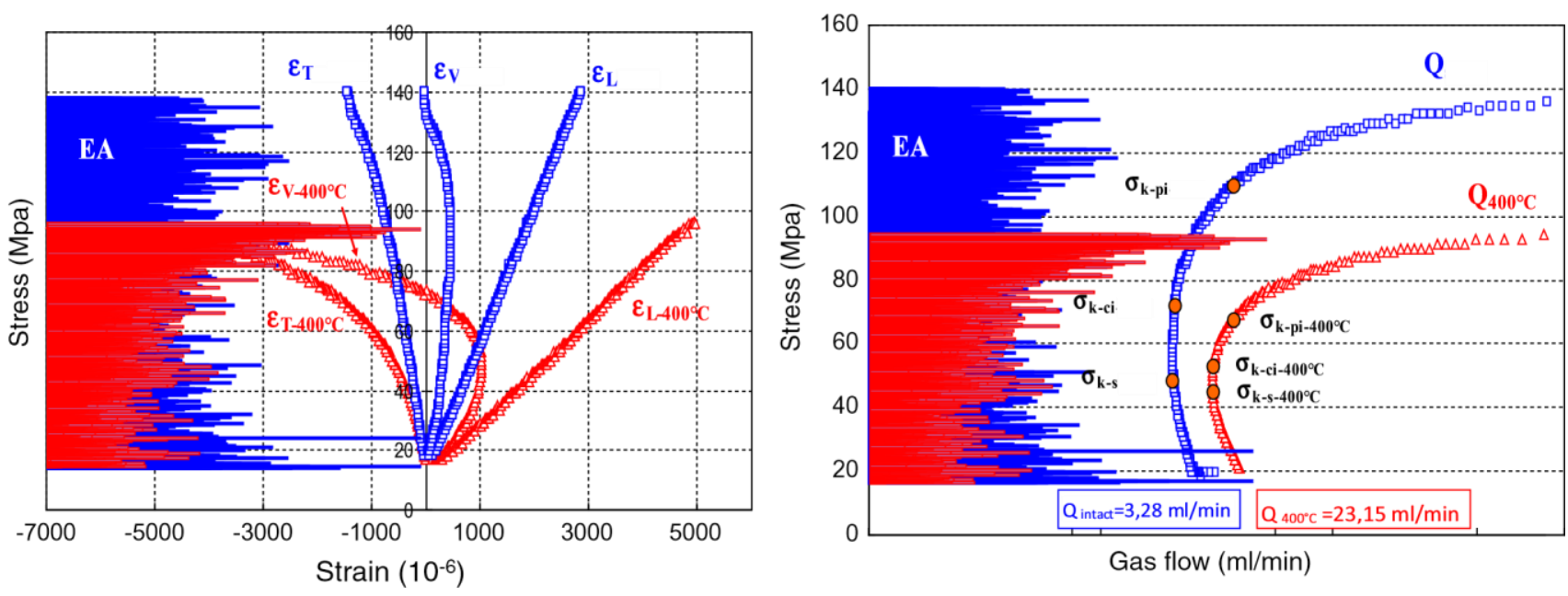

(a)

(b)

Figure 7 Curves of stress-strain (a) and stress-gas flow (b) of PP-concrete before and after the thermal degradation at $400{ }^{\circ} \mathrm{C}$.

Compressive strength and elastic modulus

Figures 8 and 9 show the evolution of compressive strength and Young's modulus of intact and thermally damaged concretes at $400{ }^{\circ} \mathrm{C}$.

We find that before thermal treatment, the fiber influences hardly the compressive strength and the elastic modulus of the UHPC specimens, except for the steel fiber which itself has a high resistance. The PP mixtures present a decrease in the mechanical properties which can be explained by a weak adherence between the PP fibers and the cementitious matrix.

As shown in Table 4 , after heating at $400{ }^{\circ} \mathrm{C}$, the compressive strength decreases by about $30 \%$ for all the specimens. There is no clear difference between organic and mineral concretes. These decreases are expected because heating causes cracks in the cement paste and separation at the interfaces between the cement paste and the aggregates or the fibers. Consequently, when the heated samples are mechanically loaded, stresses concentrate on these defaults and induce early brittle failure of the concrete.

The influence of the heating is more significant if the Young modulus is considered. The relative variation reaches $60 \%$. This means that the heating causes also a loss of stiffness in the cement paste. It is likely to be a consequence of the decomposition and the degradation of the CSH gel in the cement paste.

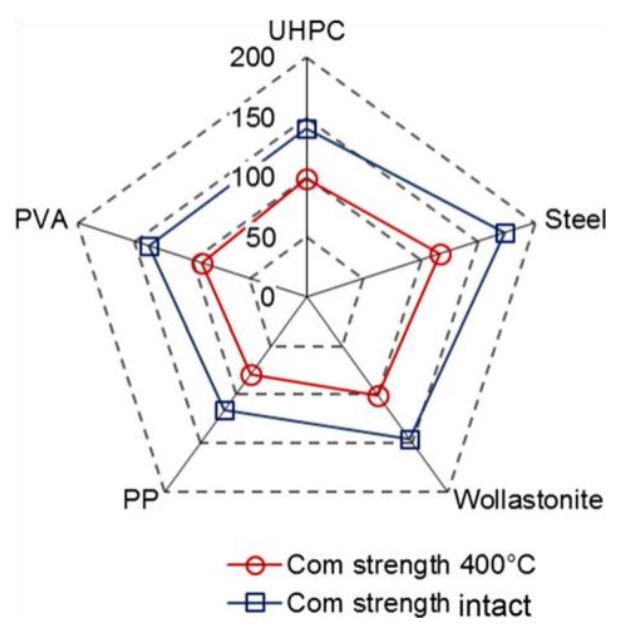

Figure 8 Compressive strength (MPa) of intact and thermally damaged concretes at $400{ }^{\circ} \mathrm{C}$.

DOI 10.1007/s10853-016-0233-9 


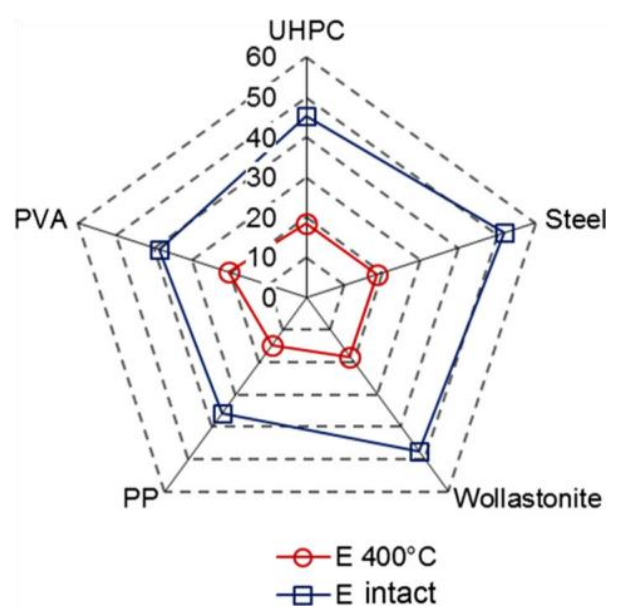

Figure 9 Elastic modulus (GPa) of intact and thermally damaged concretes at $400{ }^{\circ} \mathrm{C}$.

Table 4 Mechanical properties of intact and thermally damaged concretes at $400{ }^{\circ} \mathrm{C}$

\begin{tabular}{|c|c|c|c|c|c|c|}
\hline \multirow[t]{2}{*}{ Concretes } & \multicolumn{2}{|l|}{ Initial state } & \multicolumn{2}{|l|}{ After $400^{\circ} \mathrm{C}$} & \multicolumn{2}{|c|}{ Relative degradation (\%) } \\
\hline & $\sigma_{c}(\mathrm{MPa})$ & $\mathrm{E}(\mathrm{GPa})$ & $\sigma_{c}(\mathrm{MPa})$ & $\mathrm{E}(\mathrm{GPa})$ & $\Delta_{\mathrm{r}}$ & $\Delta \mathrm{E}$ \\
\hline UHPC & $141 \pm 0.25 \%$ & $45.3 \pm 8.44 \%$ & $98.5 \pm 1.17 \%$ & $18.5 \pm 9.43 \%$ & 30.1 & 59.2 \\
\hline \multicolumn{7}{|l|}{ UHPFRC } \\
\hline Steel & $173.2 \pm 1.32 \%$ & $51.8 \pm 14.17 \%$ & $116.5 \pm 2.13 \%$ & $18.4 \pm 3.16 \%$ & 32.7 & 64.4 \\
\hline Wollastonite & $145.5 \pm 0.75 \%$ & $47.5 \pm 3.23 \%$ & $101.2 \pm 0.91 \%$ & $18.4 \pm 2.12 \%$ & 30.4 & 61.3 \\
\hline $\mathrm{PP}$ & $116.5 \pm 1.52 \%$ & $35.9 \pm 9.39 \%$ & $79 \pm 2.01 \%$ & $14.8 \pm 0.38 \%$ & 32.2 & 58.8 \\
\hline PVA & $137.7 \pm 4.26 \%$ & $38.8 \pm 2.41 \%$ & $91.5 \pm 0.82 \%$ & $20.5 \pm 2.19 \%$ & 33.6 & 47.2 \\
\hline
\end{tabular}

Evolution of cracking thresholds

As shown in Figs. 10 and 11, we find that the use of fibers increases the threshold of initial cracking ( $\left.\sigma_{\mathrm{k}-\mathrm{ci}}\right)$ and that of unstable cracking $\left(\sigma_{\mathrm{k}-\mathrm{pi}}\right)$. Therefore, the fibers clearly restrain the cracking process in concrete under the mechanic loading, because they contribute to block the brutal propagation and the coalescence of cracks [31-33].

However, we can see that the thermal damage results a decrease in the initiation threshold of the stable crack $\left(\sigma_{\mathrm{k}-\mathrm{ci}}\right)$ and in the propagation threshold of the unstable crack $\left(\sigma_{\mathrm{k}-\mathrm{pi}}\right)$. This can be explained by the fact that the heating generates a greater number of stress concentration points, which can induce the initiation of new cracks and their coalescence. 


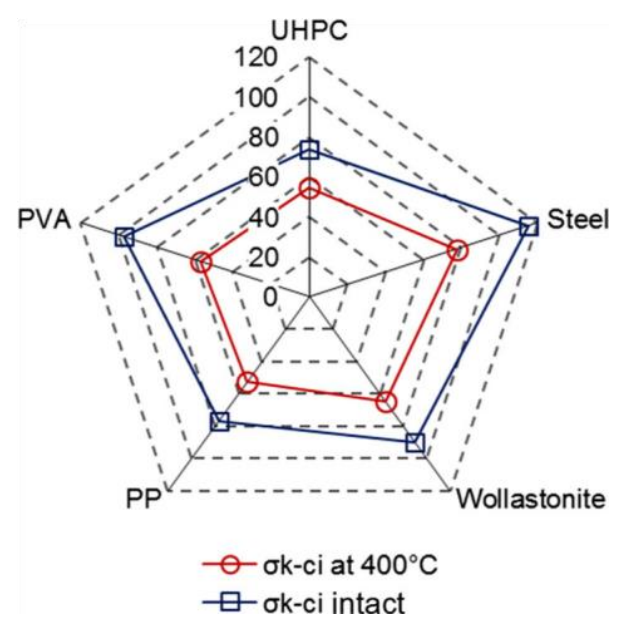

Figure 10 Initial cracking threshold $\left(\mathrm{r}_{\mathrm{k}-\mathrm{ci}}\right)$ in $\mathrm{MPa}$ of intact and thermally damaged concretes at $400{ }^{\circ} \mathrm{C}$.

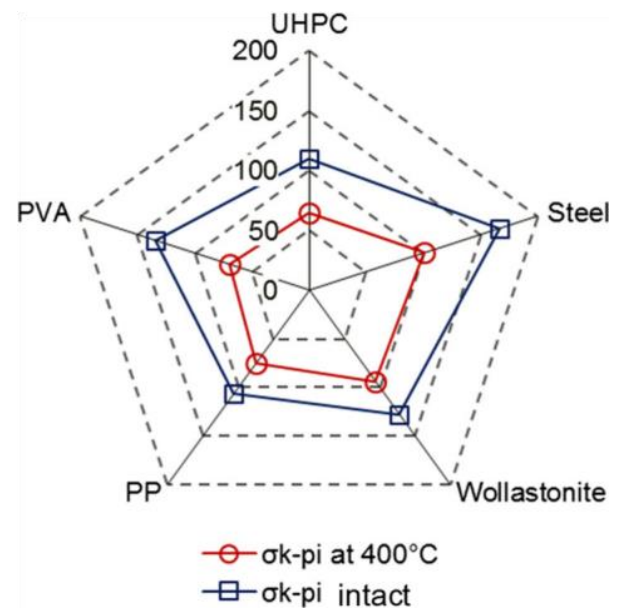

Figure 11 Unsteady cracking threshold $\left(\mathrm{r}_{\mathrm{k}-\mathrm{pi}}\right)$ in MPa of intact and thermally damaged concretes at $400{ }^{\circ} \mathrm{C}$.

\section{Conclusion}

The effects of thermal damage on physical and mechanical properties of UHPFRC have been investigated by measuring gas permeability, P-wave velocity, compressive strength, elastic modulus, and cracking behavior.

We find that the fibers incorporation increases the amount of interfaces between the cement paste and the aggregates. Consequently, if the fiber-reinforced concretes are subjected to temperature increase, the damage occurred not only in the cement paste (overall damage) but also at the interfaces (located damage). In addition, when the melting of the organic fibers occurs, it creates interconnections between the pores and causes a considerable increase of gas permeability. This behavior has a good interest when a fire occurs in a concrete-based structure since the melting of the fibers allows the exhaust of the steam and reduces the risk of explosion. The degradation of the cement paste and the fibers interfaces can also be estimated by P-waves velocity measurement, but this technique does not take into account the interconnections of the porous network; thus, we can not show a significant difference between organic and mineral fiber.

The study of mechanical behavior showed that the heat treatment at $400{ }^{\circ} \mathrm{C}$ causes a decrease in the compressive strength (about $30 \%$ ). These could be explained by the creation of new cracks in the cement paste and the loss of cohesion matrixaggregates/fibers under the effect of high temperature. The decrease in the mechanical properties is more significant if the 
Young modulus is considered (about $60 \%$ ). This means that the heating causes also a loss of stiffness in the cement paste. It is likely to be a consequence of the decomposition and the degradation of the CSH gel in the cement paste.

However, we can see that the thermal damage results a decrease in the threshold of initial cracking

$\left(\mathrm{r}_{\mathrm{k}-\mathrm{c} i}\right)$ and that of unstable cracking $\left(\mathrm{r}_{\mathrm{k}-\mathrm{p}}\right)$. This can be explained by the fact that the heating generates a greater number of stress concentration points, which can induce the initiation of new cracks and their coalescence.

\section{Compliance with ethical standards}

\section{Conflict of interest}

The authors of this paper certify that they have no affiliations with or involvement in any organization or entity with any financial interest, or nonfinancial interest in the subject matter or materials discussed in this manuscript.

\section{References}

[1] Tjiptobroto P, Hansen W (1991) Mechanism for tensile strain hardening in high performance cement-based fiber reinforced composites. Cem Concr Compos 13:265-273

[2] Swamy RN (1987) High-strength concrete-material properties and structural behaviors. ACI SP-87, American Concrete Institute, Detroit, pp 110-146

[3] Palmquist SM, Jansen DC (2001) Postpeak strain-stress relationship for concrete in compression. Mater J 98(3):213-219

[4] HsuLS,Hsu T(1994) Stressstrain behavior ofsteel-fiberhighstrength concrete under compression. Struct J 91(4):448-457

[5] Lu XB, Cheng-Tzu TH (2006) Behavior of high strength concrete with and without steel fiber reinforcement in triaxial compression. Cem Concr Res 36(9):1679-1685

[6] Wille K, El-Tawil S, Naaman AE (2014) Properties of strain hardening ultra high performance fiber reinforced concrete (UHP-FRC) under direct tensile loading. Cem Concr Compos 48:53-66

[7] Nataraja MC, Dhang N, Gupta AP (1999) Stress-strain curves for steel-fiber reinforced concrete under compression. Cem Concr Compos 21(5):383-390

[8] Bazant ZP (1997) Analysis of pore pressure, thermal stress and fracture in rapidly heated concrete. In: Proceeding of the INT workshop on fire performance of high strength concrete, NIST, Gaithersburg, 13-14 February 1997

[9] Mier V (1997) Fracture processes of concrete: assessment of material parameters for fracture models, monography. CRC Press, Boca Raton. ISBN 0-8493-9123-7

[10] Noumowe A (2005) Mechanical properties and microstructure of high strength concrete containing polypropylene fibres exposed to temperatures up to 200C. Cem Concr Res 35(11):2192-2198

[11] Liu X, Ye G, De-Schutter G, Yuan Y, Taerwe L (2008) On the mechanism of polypropylene fibres in preventing fire spalling in selfcompacting and high-performance cement paste. Cem Concr Res 38(4):487-499

[12] Menou A (2004) Etude du comportement thermome'canique des be'tons a' haute tempe'rature: approche multi e'chelles de l'endommagement thermique. Thesis, Universite' de Pau et des pays de l'Adour, France

[13] Sim JS, Park CW, Moon DY (2005) Characteristics of basalt fiber as a strengthening material for concrete structures. Composites B 36(6-7):504-512

[14] Lau A, Anson M (2006) Effect of high temperatures on high performance steel fibre reinforced concrete. Cem Concr Res 36(9):16981707

[15] Markovic I (2006) High performance hybrid fiber concrete development and utilization. Thesis, University of Van Belgrado, Serbia

[16] Bazant ZP (1997) Analysis of pore pressure, thermal stress and fracture in rapidly heated concrete. In: Proceeding of the INT workshop on fire performance of high strength concrete, NIST, Gaithersburg, 13-14 February 1997

[17] William K, Rhee I, Xi Y (2005) Thermal degradation of heterogeneous concrete materials. J Mater Civ Eng 17(3):276-285 
[18] Miloud B (2005) Permeability and porosity characteristics of steel fiber reinforced concrete. Asian J Civ Eng 6(4):317-330

[19] Carcasse`s M, Abbas A, Ollivier J-P, Verdier J (2002) An optimised preconditioning procedure for gas permeability measurement. Mater Struct 35:22-27

[20] ASTM D4525-90(1995)e1 (1990) Standard test method for permeability of rocks by flowing air. ASTM International, West Conshohocken, PA

[21] Komlos K, Popovics S, Nurnbergerova T, Babal B, Popovics JS (1996) Ultrasonic pulse velocity test of concrete-properties as specified in various standards. Cem Concr Compos 18(5):357-364

[22] Naffa SO, Goueygou M, Piwakowski B, Buyle-Bodin F (2002) Detection of chemical damage in concrete using ultrasound. Ultrasonics 40(1-8):247-251

[23] Hauwaert AV, Thimus JF, Delannay F (1998) Use of ultrasonics to follow crack growth. Ultrasonics 36(1-5):209-217

[24] Eberhardt E, Stead D, Stimpson B (1999) Quantifying progressive pre-peak brittle fracture in rock during uniaxial compression. Int J Rock Mech Min Sci 36:361-380

[25] Butt SD (1999) Development of an apparatus to study the gas permeability and acoustic emission characteristics of an outburst-prone sandstone as function of stress. Int J Rock Mech Min Sci 36:1079-1085

[26] Chaki S, Takarli M, Prince-Agbodjan W (2008) Influence of thermal damage on physical properties of a granite rock: porosity, permeability and ultrasonic wave evolutions. Constr Build Mater 22(7):1456-1461

[27] Takarli M, Prince-Agbodjan W, Siddique R (2008) Damage in granite under heating/cooling cycles and water freeze- thaw condition. Int J Rock Mech Min Sci 45(7):1164-1175

[28] Hannawi K, Bian H, Prince-Agbodjan W, Raghavan B (2016) Effect of different types of fibers on the microstructure and the mechanical behavior of ultra-high performance fiberreinforced concretes. Composite B 86:214-220

[29] Takarli M, Prince-Agbodjan W (2007) Permeability and P-wave velocity change in granitic rocks under freeze-thaw cycles. Geomech Geoeng 2(3):227-234

[30] Greszczuk LB (1969) Theoretical studies of the mechanics of the fiber matrix interface in composites. In: Interfaces in composites committee D-30, American society for testing and materials, Philadelphia, p 17

[31] Banthia N, Sappakittipakorn M (2007) Toughness enhancement in steel fiber reinforced concrete through fiber hybridization. Cem Concr Res 37:1366-1372

[32] Toutanji Houssam A (1999) Properties of polypropylene fiber reinforced silica fume expansive-cement concrete. Constr Build Mater 13:171-177

[33] Li FM (1998) Fracture characterization of fiber reinforced concrete in direct uniaxial tension. Thesis, Department of science and technology, University of Hong Kong, Hong

Kong 